\title{
Breast Lumps in NAUTH, Nnewi :A 5 year Review
}

\section{OA Egwuonwu* \\ SNC Anyanwu \\ GU Chianakwana \\ EC Ihekwoaba}

Department of Surgery

Nnamdi Azikiwe University

Teaching Hospital, Nnewi.

All Correspondence:

Dr OA Egwuonwu

Department of Surgery

NAUTH, Nnewi

E-mail:Egwuobi@yahoo.com
Abstract

\section{Background}

Breast lump is the most common reason for presenting to breast clinics. It is a source of great anxiety to a female when it is discovered.

\section{Objective}

This study aims at a clinico-pathologic review of breast lump as a presenting complaint.

\section{Material and Methods}

A 5-year retrospective analysis of 550 patients presenting with a complaint of breast lump to the breast clinic of Nnamdi Azikiwe University Teaching Hospital (NAUTH) Nnewi, from January 2004 December 2008.

\section{Results}

Breast lump was the presenting complaint in 550(82.8\%) of 664 patients presenting to the breast clinic. The lump was painless in $458(83.3 \%)$, associated with pain and breast ulcer in 59(10.7\%) and 33(6.0\%) patients respectively. Females constitute 548(99.6\%) with only 2(0.4\%) males. There was no palpable lump in 23 patients $(4.2 \%)$ on clinical examination and only 54 patients $(9.7 \%)$ had > 1 lump.

The clinical diagnosis were breast cancer in 260 patients $(47.3 \%)$, fibroadenoma in $175(31.8 \%)$, fibrocystic changes in $67(12.2 \%)$ patients. The others were different types of benign diseases. Histopathology report was available in 294 patients with $161(54.8 \%), 56(19.0 \%)$ and $46(15.6 \%)$ patients diagnosed respectively as having invasive cancer, fibroadenoma, and fibrocystic changes.

\section{Conclusion}

Our study shows that breast lump was the most common presenting complaint with most patients not presenting early. Fewer lumps are discovered by breast self examination. The finding that breast cancer was slightly more common than benign breast lesions is at variance with most studies probably due to proliferation in our environment of private owned hospitals by general practitioners where most of the benign lesions are probably managed. But the finding of fibroadenoma as the most common of the benign lesions is similar to that reported by other researchers in Nigeria and other parts of the world.

Key Words: breast lump, Nnewi, Review

\section{Introduction}

$\mathrm{B}_{\mathrm{r}}^{\mathrm{res}}$ reast lump is the most common reason for presenting to breast clinics. Most of these patients, however, are in a state of heightened anxiety until they have undergone specialist assessment, the necessary investigations and eventual reassurance. The majority of patients referred to a breast clinic is said to have benign disease. ${ }^{1-3}$ Fibroadenoma is the most common of the benign breast diseases. ${ }^{4-7}$ this study aims to audit the clinicopathologic features of patients with breast lump at NAUTH.

\section{Methodology}

Nnamdi Azikiwe University Teaching Hospital [NAUTH] Nnewi, is a tertiary hospital located in the South Eastern part of Nigeria. This hospital plays a major role in health care delivery in this part of the country. The data on all patients who presented with history of breast lump to the surgical outpatient clinic of NAUTH from 1st January 2004 to 31st December 2008 were retrospectively analysed. Information on age at presentation, parity, duration of symptom before presentation, mode of discovery of lump, previous breast disease, side and quadrant of breast affected, maximum diameter of breast lump, clinical 
diagnosis made by the senior registrar or unit consultant, refusal or acceptance of biopsy, type of biopsy done and histology diagnosis for patients who returned with histology report were extracted from the case files.

Statistical Package for Social Sciences (SPSS) version 15.0 was used for data analysis. Simple frequencies were determined for variables.

\section{Results}

Breast lump was the presenting complaint in $550(82.8 \%)$ of 664 patients presenting to the breast clinic. Females constitute 548(99.6\%) with only $2(0.4 \%)$ males. The mean age of patients presenting with breast lump was 37.5 years [Range 13-80years]. Five hundred and forty-six (99.3\%) were Igbos, as shown in table 1 .

Table 1: Age Distribution.

\begin{tabular}{cc}
\hline Age in Years & Frequency \\
\hline$<20$ & 59 \\
$21-30$ & 148 \\
$31-40$ & 130 \\
$41-50$ & 115 \\
$51-60$ & 60 \\
$61-70$ & 22 \\
$71-80$ & 16 \\
Total & $\mathbf{5 5 0}$ \\
\hline
\end{tabular}

$423(77.2 \%)$ were premenopausal and $2(0.4 \%)$ premenstrual. Nulliparity was seen in 208 (44.2\%). The lump was painless in $458(83.3 \%)$, associated with pain and breast ulcer in $59(10.7 \%)$ and $33(6.0 \%)$ patients respectively. Duration from discovery of lump to presentation was $<1$ months in 102 (18.5\%), 1-3 months 98 (17.8\%), 3-6 months 73 (13.3\%), 6-12 months 71 (12.9\%), > 12 months in $192(35 \%)$ and ranges from 2 days to 19 years. The duration was not documented in 14 patients.

The lumps were discovered by breast self examination (BSE) in $79(14.3 \%$ ) patients, they were accidental discovery in $293(53.3 \%)$ patients. Attention was drawn to the lump by breast pain in 66 $(12.0 \%)$, while the discovery was made by the doctor and the patients husband in $21(3.8 \%)$ and $2(0.4 \%)$ respectively. Mode of discovery was not stated in 89 (16.2\%) patients. The lumps were increasing in size in $223(49.6 \%)$, decreasing in $17(3.8 \%)$, stationary in $178(38.4 \%)$, fluctuating in $9(2 \%)$.
The left breast was slightly more affected 262 (48.2\%) than the right 252 (46.3\%). The upper outer quadrant is the most common site of occurrence 165 (30\%) followed by the upper inner quadrant 90 $(16.4 \%)$, lower outer quadrant $50(9.1 \%)$, central 44 (8\%), whole breast $41(7.5 \%)$, multiple quadrant 33 (6\%), lower inner quadrant 19 (3.5\%), no palpable lump $23(4.2 \%)$ and in $85(15.5 \%)$ patients the involved quadrant was not stated. Multiple lumps were found in $54(9.7 \%)$ patients. The mean diameter of the lumps was $6 \mathrm{~cm}$ [Range $0.5-30 \mathrm{~cm}$ ]. The number of patients admitting to previous history of breast disease was 43 , with 30 having benign breast lesion. The clinical diagnosis (Table 2)

Table 2: Clinical Diagnosis.

\begin{tabular}{lcc}
\hline Clinical Diagnosis & Frequency & Percent \\
\hline Breast cancer & 260 & 47.3 \\
Fibroadenoma & 175 & 31.8 \\
Fibrocystic disease & 67 & 12.2 \\
Normal breast & 8 & 1.5 \\
Breast Abscess & 6 & 1.1 \\
Duct ectasia & 5 & 0.9 \\
Galactocele & 5 & 0.9 \\
Inflammatory mass & 4 & 0.7 \\
Mastitis & 4 & 0.7 \\
Phyllodes Tumor & 3 & 0.5 \\
Mondor's disease & 2 & 0.4 \\
Recurrent Cancer & 2 & 0.4 \\
Kaposi Sarcoma & 1 & 0.2 \\
Others & 8 & 1.5 \\
Total & $\mathbf{5 5 0}$ & $\mathbf{1 0 0 \%}$ \\
\hline
\end{tabular}

Were breast cancer in 260 patients (47.3\%), fibroadenoma in 175 (31.8\%), fibrocystic changes in $67(12.2 \%)$ patients. The others were different types of benign diseases.

\section{Histopathology Diagnosis}

Biopsy was done on 346(62.9\%) patients, $165(30 \%)$ refused biopsy, and 39(7.1\%) patients did not require biopsy. The types of biopsies done were excision in $181(52.3 \%)$ patients, $155(44.8 \%)$ had incision biopsy, $5(1.45 \%)$ core-cut biopsy, and 5(1.45\%) FNAC. Histopathology report (Table 3) was available in 294 patients, with 161(54.8\%), $56(19.0 \%)$ and $46(15.6 \%)$ patients diagnosed respectively as having invasive cancer, fibroadenoma, and fibrocystic changes. However, on clinical ground benign breast diseases constitute $53.3 \%$ (293 cases) with malignant being $46.7 \%$. The mean age for breast cancer was 46.3 years, median 45 years range $26-78$ years with a peak of 50 years. For 
fibroadenoma, mean age was 23.2 years, median 22years, range 18-39 years with a peak age of 21 years and for fibrocystic changes, mean was 37 , median 35.5, range 16-80 years with peak age of 32 years. The breast lumps ranges in size from $0.5-30$ $\mathrm{cm}, 0.5-20 \mathrm{~cm}, 0.5-11 \mathrm{~cm}$ for breast cancer, fibroadenoma and fibrocystic changes respectively.

Table 3: Histopathology Diagnosis.

\begin{tabular}{lll}
\hline Histology Diagnosis & Frequency & Percent \\
\hline Breast Cancer & 161 & 54.8 \\
Fibroadenoma & 56 & 19.0 \\
Fibrocystic Disease & 46 & 15.6 \\
DCIS & 3 & 1.0 \\
Fat necrosis & 4 & 1.4 \\
Phyllodes ( benign) & 4 & 1.4 \\
Phyllodes (borderline) & 1 & 0.3 \\
Phyllodes (malignant) & 1 & 0.3 \\
Tuberculous Mastitis & 3 & 1.0 \\
Adenosis & 3 & 1.0 \\
Abscess & 3 & 1.0 \\
Tubular adenoma & 2 & 0.7 \\
Others & 7 & 2.4 \\
Total & $\mathbf{2 9 4}$ & $\mathbf{1 0 0 . 0}$ \\
\hline
\end{tabular}

\section{Discussion}

The fear that a breast lump might be cancerous makes patient to present to the hospital. Fortunately, studies have shown that majority of patients presenting to a breast clinic have benign disease. ${ }^{1-3}$ Breast lump was the most common presenting complaint (82.8\%) to the symptomatic breast clinic in NAUTH. Most of these patients still present late to the hospital with $81.5 \%$ presenting after a month of noticing the lump. Other worker in Nigeria studying breast cancer also noted that the trend is toward late presentation. Okobia et $\mathrm{al}^{8}$ noted that $78 \%$ of their patients reported after 3 months of symptoms while Atoyebi et $\mathrm{al}^{9}$ noted that $64 \%$ of their patients presented after 6 months, earliest been at 2 weeks in a nurse.

Only small proportions (14.3\%) of patients discover their lump by BSE, in majority (53.3\%) breast lump was an accidental discovery. Jebbin et. al. ${ }^{10}$ working in Port-Harcourt noted that $20 \%$ of their study population perform BSE monthly. This may support the fact that only $14.3 \%$ of our patients discover their breast lump by BSE. There is need to intensify BSE campaign in our environment to see if it would impact on early presentation and detection of breast lumps. Following breast biopsies, histopathology revealed that breast cancer $(54.8 \%)$ is slightly commoner than benign breast disease $(45.2 \%)$. The percentage of benign cases in our series is lower than $72.6 \%, 90 \%, 71.3 \%$ and $73 \%$ reported respectively in $\mathrm{Eku}^{11}$, Benin ${ }^{12}$, Zaria ${ }^{13}$ and Kano ${ }^{14}$ recently. But it compares with the $48 \%$ reported in Ibadan by Ajayi et $\mathrm{al}^{15}$ more than 30 years ago. When Ibadan was one of the very few centres handling such cases. The higher rate of malignant breast lesion in this series may be due to proliferation of private hospitals in our environment with the implication that benign breast lesion are treated there while malignant cases are referred to specialized breast clinic like ours.

The most common cause of breast lumps in this series remained breast cancer $(54.8 \%)$, followed by fibroadenoma $(19.0 \%)$ and fibrocystic changes (15.6\%). Other researchers have noted fibroadenoma to be the most common cause of breast lump $p^{2,13,16,17}$, followed by fibrocystic disease, then breast cancer $^{2}$ or breast cancer then fibrocystic disease $^{4}$. In London Ellis ${ }^{18}$ from a referral hospital noted that breast cancer was the most common finding in breast biopsies just like in our center.

The age range of patients with breast lump in our study was $13-80$ years. Eltahir et $\mathrm{al}^{19}$ found the age range to be 15-91 year in their patients with breast lumps. Thus it appears that patients with breast lumps in our environment are slightly younger.

The mean age for breast cancer in our environment had been noted to be 46.2 years ${ }^{20}$, our study found 46.3 years which is very consistent with this previous finding. In the study by Carty et $\mathrm{al}^{21}$ on fibroadenoma, the age range of their study population was 15-48 years with a mean age of 28 -years. But our study noted 18-39 years age range with a mean of 23.2years, this is consistent with other reports ${ }^{11,12,14,22}$. Of the minor breast lesions, this study found $6(2 \%)$ cases of phyllodes tumour and 3 cases of tuberculous mastitis. The series by Anyanwu ${ }^{23} 20$ years ago reported only a case of phyllodes tumour but no case of tuberculous mastitis was reported. Also Akhator ${ }^{11}$ reported only one case of phyllodes tumour with two cases of tuberculous mastitis. Though our study reported greater number of phyllodes tumour, this condition is still rare and is still within the $2 \%-4.4 \%$ rate reported ${ }^{24}$. 


\section{Conclusion}

Our study shows that breast lump was the most common presenting complaint with most patients not presenting early. Fewer lumps are discovered by breast self examination. The finding that breast cancer was slightly more common than benign breast lesions is at variance with most studies probably due to proliferation in our environment of private owned hospitals by general practitioners where most of the benign lesions are probably managed. But the finding of fibroadenoma as the most common of the benign lesions is similar to that reported by other researchers in Nigeria and other parts of the world.

\section{References}

1. Osime OC, Ohanaka EC. Analysis of five-year breast biopsies carried out in the University of Benin Teaching Hospital Benin City. Niger Postgrad Med J. 2008 ;15(3):160-163.

2. Ohene-Yeboah MO. An audit of excised breast lumps in Ghanaian women. West Afr J Med. 2005;24(3):252-255.

3. Clegg-Lamptey JN, Aduful HK, Yarney J, AduAryee NA, Vanderpuye V, Kyereh M, et al. Profile of breast disease at a self-referral clinic in Ghana. Nepal Med Coll J. 2004;6(2):129-132.

4. Oluwole SF, Freeman HP. Analysis of benign breast lesions in blacks._Am J Surg. 1979 Jun;137(6):786-789.

5. Sönmez K, Türkyilmaz Z, Karabulut R, Demiroðullari B, Ozen IO, Moralioðlu S, Surgical breast lesions in adolescent patients and a review of the literature. Acta Chir Belg._2006 Jul-Aug;106(4):400-404.

6. Adeniji KA, Adelusola KA, Odesanmi WO. Benign disease of the breast in Ile-Ife: a 10 year experience and literature review. Cent Afr J Med. 1997;43(5):140-143.

7. Ihekwaba FN. Benign breast disease in Nigerian women: a study of 657 patients. J R Coll Surg Edinb. 1994;39(5):280-283.

8. Okobia MN, Ahigbe JU. Pattern of malignant disease at University of Benin Teaching Hospital. Trop Doct 2005;35(2):9-12.

9. Atoyebi OA, Atimomo CE, Adesanya AA, Beredugo BK, da Rocha-Afodu JT. An appraisal of 100 patients with breast cancer seen at the Lagos University Teaching Hospital. Nig. Qt. J Hosp. Med. 1997;7(2):104-108.
10. Jebbin NJ, Adotey JM. Attitudes to, knowledge and practice of breast self-examination (BSE) in Port Harcourt. Nig J Med 2004;13(2):166-170

11. Akhator A. Benign breast masses in Nigeria. Nig J Surg. 2007;17(2):105-108

12. Okobia MN, Osime U. A clinicopathological study of benign breast disease in Benin City, Nigeria. Nig J Surg. 1998;5(2):64-69

13. Yusuf LMD, Odigie VI, Mohammed A. Breast masses in Zaria, Nigeria. Annals of African Medicine. 2003;2(1):13-16.

14. Ochicha O, Edino ST, Mohammed AZ, Amin $\mathrm{SN}$. Benign breast lesions in Kano. Nig $\mathrm{J}$ of Surgical Research. 2002;4:1-5.

15. Ajayi OO, Adekunle O. Non-malignant breast masses in an African population. Br. J. Surg. 1973;60:465-468

16. Adesunkanmi AR, Agbakwuru EA. Benign breast disease at Wesley Guild Hospital, Ilesha, Nigeria. West Afr J Med. 2001;20(2):146-151

17. Otu AA. Benign breast tumours in an African population. J R Coll Surg. 1990;35(6):373-375

18. Ellis H. Review of general surgery 1984-85. Postgraduate Medical Journal. 1985; 61: 941956

19. Eltahir A, Jibril JA, Squair J, Heys SD, Ah-See AK, Need-Ham G, et al. The accuracy of "onestop" diagnosis for 1110 patients presenting to a symptomatic breast clinic. J R Coll Surg Edinb. 1999; 44:226-230

20. Anyanwu SNC. Temporal trends in breast cancer presentation in the third world. J Exp Clin Cancer Res. 2008; 27(1): 17

21. Carty NJ, Carter C, Rubin C, Ravichandran D, Royle GT, Taylor I. Management of fibroadenoma of the breast Ann R Coll Surg Engl 1995; 77: 127-130

22. Anyanwu SNC. Fibro-adenoma of the breast in Nigerian Igbos. S Afr Med J. 2000;90(12):12231226

23. Anyanwu SNC. Spectrum of breast disease among Nigerian Igbos. Orient Journal of Medicine.1990;2(1):14-15

24. Petrek JA. Phyllodes tumours. In Harris JR, Lippman ME, Morrow M, Osborne CK, ed. Harris disease of breast. $2^{\text {nd }}$ Ed. Lippman, Lippincott Williams and Wilkins;2000:47. 